\title{
Tolerance in the Communicative Culture of Modern Educational Manager
}

\section{Tolerancia en la cultura comunicativa del gestor educativo moderno}

\author{
Mariana Sokol \\ Doctor of Pedagogical Sciences, Professor of Romanic-German Philology Department, Ternopil
} Volodymyr Hnatiuk National Pedagogical University. Ternopil, Ukraine. ORCID ID 0000-0003-3876-026X

\section{Rozlutska Galyna}

Doctor of Pedagogical Sciences, Professor of General pedagogy and High school pedagogy Department, Uzhhorod National University. Uzhhorod, Ukraine.

ORCID ID 0000-0001-9062-5466.

\section{Shaparenko Khrystyna}

Doctor of Pedagogical Sciences, Associate Professor, Professor of the Department of Theory and Methods of Preschool Education, Dean of the Faculty of Preschool, Special Education and History Municipal Establishment "Kharkiv Humanitarian Pedagogical Academy” of Kharkiv Regional

Council, Ukraine.

ORCID ID 0000-0003-3616-2282.

\section{Olha Hvozdyak}

Associate Professor, PhD in Pedagogy, Head of German Philology Department. Uzhhorod National University. Uzhhorod, Ukraine.

ORCID ID 0000-0002-5760-576X.

\section{Gorodyska Violetta}

Associate Professor, PhD in Pedagogy. Department of general pedagogy and preschool education, DSPU "Drohobych state pedagogical university". Drohobych, Ukraine.

\section{ORCID ID 0000-0002-2415-4317.}

\section{Ivakh Svitlana}

Associate Professor, PhD in Pedagogy. Department of general pedagogy and preschool education, DSPU "Drohobych state pedagogical university". Drohobych, Ukraine.

ORCID ID 0000-0003-0596-6835.

* Correspondence

Email: maryanasokol@ukr.net

\section{Citation:}

Mariana Sokol, Rozlutska Galyna, Shaparenko Khrystyna, Olha Hvozdyak, Gorodyska Violetta, Ivakh Svitlana. (2021). Tolerance in the Communicative Culture of Modern Educational Manager. . Propósitos y Representaciones, 9 (SPE3), e1170. Doi: http://dx.doi.org/10.20511/pyr2021.v9nSPE3.1170 


\begin{abstract}
Cultural, racial, social, religious, ethnic heterogeneity of educational groups is a problem of modern education in the context of integration and globalization. This often becomes a reason for misunderstandings, sometimes aggression in the interaction of representatives of opposing worldviews, preferences or traditions. Tolerance in the communicative culture of the educational manager, activated at the level of management structures and broadcast vertically and horizontally through the education system through pedagogical teams to all categories of consumers of educational services, will be able to prevent this. The aim of the article is to outline the role of tolerance in the communicative culture of the modern education manager. According to the purpose the following tasks of research have been defined: - to analyze sources of various branches of science and to find out meanings of basic concepts; - to outline the features of management in education in communication area; - to define its structure, establish relationships between components and develop a structural and semantic model of tolerance in the communicative culture of the education manager. The following research methods have been used to study the backgrounds of the problem: information, terminology, analysis, synthesis, methods of scientific research. The comparativetypological method has been used to compare, identify signs of similarities and differences between phenomena and facts Methods of forecasting and theoretical modeling have been used in the development of structural and semantic model. Systematization, classification and use of structuralfunctional analysis have been contributed to the generalization of the research results. Interdisciplinary approaches (sociocultural and multicultural) to the study of management, along with axiological, holistic, systemic, activity and synergetic are the methodological basis of the study. Methodological principles (synergetic, complementarity, activity (action and creative), interaction between the subjects of the educational process, convergence from the abstract to the concrete) have been applied. The scientific novelty of the research: - for the first time the meaning and valuesemantic nature of tolerance in the communicative culture of an educational manager have been determined; - the determinants of educational management in the projection on communication have been clarified; - the interrelations between the components have been established and the possibilities for realization of tolerance in different directions of communicative culture have been revealed; - a structural and semantic model of tolerance in the communicative culture of the education manager has been developed. The main results of the study are the analysis of the source base from the standpoint of scientific approaches to various fields of knowledge (economics, sociology, psychology, pedagogy, management, culturology, etc.), which made it possible to identify a modern interpretation of "education management". The determinants of educational management as a component of social in the context of intangible, spiritual resource of education have been revealed. The similar and different characteristics of the managerial activity of the education manager and the pedagogical worker have been outlined. The essence, origin, structure, types and directions of functioning of communicative culture of the manager of education have been determined.
\end{abstract}

Key words: education, management in the field of education, education manager, tolerance, communicative culture.

\title{
Resumen
}

La heterogeneidad cultural, racial, social, religiosa y étnica de los grupos educativos es un problema de la educación moderna en el contexto de la integración y la globalización. Esto a menudo se convierte en una razón para malentendidos, a veces agresión en la interacción de representantes de visiones del mundo, preferencias o tradiciones opuestas. La tolerancia en la cultura comunicativa del gestor educativo, activada a nivel de estructuras de gestión y difundida vertical y horizontalmente a través del sistema educativo a través de equipos pedagógicos a todas las categorías de consumidores de servicios educativos, podrá prevenir esto. El objetivo del artículo es esbozar el papel de la tolerancia en la cultura comunicativa del gestor educativo moderno. Según el propósito, se han definido las siguientes tareas de investigación: - analizar fuentes de diversas ramas de la ciencia y descubrir significados de conceptos básicos; - describir las características de la gestión en educación en el área de la comunicación; - definir su estructura, establecer relaciones entre 
componentes y desarrollar un modelo estructural y semántico de tolerancia en la cultura comunicativa del gestor educativo. Se han utilizado los siguientes métodos de investigación para estudiar los antecedentes del problema: información, terminología, análisis, síntesis, métodos de investigación científica. Se ha utilizado el método comparativo-tipológico para comparar, identificar signos de similitudes y diferencias entre fenómenos y hechos. Métodos de predicción y modelización teórica se han utilizado en el desarrollo del modelo estructural y semántico. La sistematización, clasificación y uso del análisis estructural-funcional ha contribuido a la generalización de los resultados de la investigación. Los enfoques interdisciplinarios (socioculturales y multiculturales) del estudio de la gestión, junto con los axiológicos, holísticos, sistémicos, de actividad y sinérgicos son la base metodológica del estudio. Se han aplicado principios metodológicos (sinergia, complementariedad, actividad (acción y creativa), interacción entre los sujetos del proceso educativo, convergencia de lo abstracto a lo concreto). La novedad científica de la investigación: por primera vez se ha determinado el significado y la naturaleza semántica de valores de la tolerancia en la cultura comunicativa de un gestor educativo; - Se han aclarado los determinantes de la gestión educativa en la proyección sobre la comunicación; - se han establecido las interrelaciones entre los componentes y se han revelado las posibilidades de realización de la tolerancia en diferentes direcciones de la cultura comunicativa; - Se ha desarrollado un modelo estructural y semántico de tolerancia en la cultura comunicativa del gestor educativo. Los principales resultados del estudio son el análisis de la base de la fuente desde el punto de vista de los enfoques científicos de diversos campos del conocimiento (economía, sociología, psicología, pedagogía, gestión, culturología, etc.), que permitió identificar una interpretación moderna. de "gestión educativa". Se han revelado los determinantes de la gestión educativa como componente de lo social en el contexto del recurso espiritual intangible de la educación. Se han esbozado las características similares y diferentes de la actividad gerencial del gerente educativo y del trabajador pedagógico. Se ha determinado la esencia, origen, estructura, tipos y direcciones de funcionamiento de la cultura comunicativa del gestor educativo.

Palabras clave: Educación, Gestión En El Ámbito Educativo, Gestor Educativo, Tolerancia, Cultura Comunicativa.

\section{Problem statement in general}

Under the influence of modern civilizational challenges, values and social systems are changing. The education system as the basis of socio-cultural reproduction of society is adapting to today's requirements. The cultural, racial, social, religious, ethnic homogeneity of educational collectives is leveled in terms of integration and globalization. Often heterogeneity becomes a reason for misunderstandings, sometimes aggression in the interaction of representatives of opposing worldviews, preferences or traditions. The managerial personnel is an important resource for educational reform. However, its subject characteristics are both the result and the driving force of educational transformations. The goals determined by the management structures are transformed in the minds of the subjects of activity depending on their professional and social attitudes, criteria, norms, values, competencies, etc. The problem of updating the culture of communication of managers in the context of changing subjectivity is important for our research.

Communicative culture as a complex social phenomenon is part of the general culture of the individual, includes the achievements of social and individual life. In management, aimed at transforming external norms into internal assets, communicative culture is one of the most important professionally significant characteristics of the educator, and the manifestation of tolerance in communicative culture is a priority. Management in the education system is considered simultaneously in two aspects: as an organizational structure of education from the Ministry of Education to the teacher, and as a certain socio-psychological structure, i.e. the subjective basis of the industry. It reflects the ratio of subjective and objective qualities and functions that are personified in the job hierarchy at each level of the education system.

The aim of the study is to investigate the role of tolerance in the communicative culture of a modern education manager. According to the aim the following tasks of research have been defined: 
- to analyze sources of various branches of science and to find out essence of basic concepts, to cover features of management in education;

- to outline the structure, establish relationships between components and develop a structural and semantic model of tolerance in the communicative culture of the education manager.

Research methods. General scientific and mathematical methods have been used during the research process. Among them are methods of analysis and synthesis, methods of system approach, methods of modeling, etc. The research is based on interdisciplinary approaches to the study of educational processes and phenomena that determine the causes and motives, allow the interpretation of facts. The system approach and the use of structural-functional analysis contributed to the generalization of the research results.

The main material research. The problems of management in the field of education crystallize at the intersection of the achievements of various branches of science, such as economics, sociology, psychology, pedagogy, management, culturology, and others. The analysis of researches in the field of economics devoted to the development of management indicates that the terms "government", "administration" are used in scientific circulation (Skibytska, 2010, p. 4), as synonyms for the key concept of "management". From the standpoint of organizations management (government, administration) management is seen as a process aimed at achieving the goals of the organization by streamlining the transformation of raw materials or resources (labor, materials, funds, information, etc.) into the desired results (goods, products, services).

In pedagogical science the concept "education management" (Philosophy of Education, 2009 , p. 269) has been interpreted as one of the types of social management. It has been considered that all management is administration, but not all administration is management, because along with it there is the management of technical systems and management of biological systems.

There are the following aspects of management:

- the activity or product; subject and object;

- the structure and technology;

- the formal or declared authority and informal leadership;

- the natural gift and professional education;

- the science and art.

Social management is the management of people, the science of human being, his interests, behavior and interaction with other people since. A. Shegda (Sheregda, 2004, pp. 12-45) points out that human management always has a direct or indirect impact on human behavior, because a person can act correctly or incorrectly, while the mechanism always acts the same, according to the design or given programs. Therefore, management explains the nature of administrative work, establishes cause-and-effect relationships, and identifies the factors, conditions under which people work together more effectively.

It is important to take into account the universality of management in education. For example, the rigidity of the administrative vertical from the team to the reaction and the report, and with the public - on the principle of the supremacy of private interests. Therefore, in the horizontal dimension there are activities on a partnership basis, i.e. it is universal in nature and applies to any educational processes and systems.

It has been emphasized that the manager-administrator manages the activities of adults, who are mainly able to independently determine priorities and act based on acquired competencies and life experience. At the same time, the influence on the educational (training) team is indirect. While the teacher provides team management, communicates with participants in the educational process directly. It is noteworthy, that the educational process is not one-sided; its integral component is the interaction with parents and various social institutions. Communication is considered in terms of the interaction of individuals and groups of people who exchange knowledge, skills, abilities and performance. Communication in management is a way to meet various human needs: material or spiritual, but in educational management, material interests are not taken into account. Thus, 
educational management is a component of social in the context of intangible, spiritual resources to meet the social, cultural, cognitive needs of consumers of educational services.

According to the research (Rozlutska, Kostak, Sharkadi, 2019, p. 408) the basis of effective activity is provided by the axiologists of partnership, i.e.:

- respect for the individual;

- friendliness and positive attitude;

- trust in relationships;

- dialogue - interaction - mutual respect; distributed leadership (proactivity, the right to choose and responsibility for it, the horizontality of ties);

- social partnership (equality of the parties, voluntary commitment, binding agreements).

Thus, the difference in the perception of the classical manager and teacher-manager is manifested in the fact that the main characteristic of a professional manager is the identification of his interests with the interests of the organization in which he works, through an incentive system as a service mechanism. However, the pedagogical activities of the manager-administrator should not be excluded, for example, during the teaching of training courses, educational activities, etc.

In addition to the concept of "management in education / educational management", the terms "pedagogical management" and "didactic management" are used in scientific circulation. It has been noted that the historical concept of "pedagogical management" because of development has evolved into "educational management" (Sokol, Tsaryk, Rozlutska, 2020, p. 43). Based on the limits of action, the didactic management has been considered as part of the educational one which is functioning within the educational process.

Common to the teacher and the manager are the general requirements due to the need to effectively communicate, interact, dynamism, psychological stability, responsibility, etc. I. Zyazyun (Zyazyun, 2004, p. 48) defined a set of professional values and personal qualities of a teacher through the prism of pedagogical skills. Pedagogical skill has been considered as the highest, creative activity of the teacher that is shown in expedient use of methods and means of pedagogical interaction in each pedagogical situation. This expediency depends on two variables, namely: the quality of training and the development of individual characteristics of the teacher. The basic qualities of a teacher that allow you to manage the development of personality in the educational process: observation, empathy, dynamism, emotional stability.

Today's integration tendencies have been reflected in multicultural education, which has exacerbated the problem of identity at different levels: national, religious, linguistic. The stabilizing factor of confrontations in education was the implementation of multiculturalism principle, which is considered as the basis for the interaction of speakers of different cultures or culturally appropriate environments. Tolerance has been considered as an essential element of communicative culture. The study outlines tolerance as a component of the value basis of the communicative culture of the education manager. However, the need for a friendly or restrained attitude of the manager to differences between people in the broadest sense, the avoidance of intolerance in interaction can cause the extrapolation of previously formed social and personal values. Given the effectiveness of positive motivation as a psychological mechanism, which by force determines the reassessment of the acquired value system through self-education and self-education, the opinion of modern researchers (Barchiy, Voronova, 2020, p. 253) can assume a variety of forms and manifestations of tolerance in the communicative culture of the education manager. In addition, this allows the interpretation of tolerance as a value, practice and principle of interaction of participants in the educational process.

In world scientific community, tolerance from the first religious treatises was considered in the context of recognizing the need or possibility of working together with others to achieve the common wealth. I. Vegesh rightly remarks (Vegesh, 2019, p. 23) that tolerance has been interpreted differently at different times and in different communities, but throughout the history of human civilization it remained an important human virtue that required effort to work on. 
The paradigm of tolerance concept has been characterized by a variety of manifestations, such as: ethnic, religious, racial, social, age, gender, physical and others. The most common tokens are: impartiality, liberalism, resolution, variation, generosity, mercy, obedience, endurance, patience, moderation, long-suffering, tolerance, indulgence, pardon, indulgence, gentleness, meekness, meekness generosity, generosity, benevolence, affection, compassion, charity, respect, patronage, care. The research study will take the values of multiculturalism, practice and the principle of interaction of participants in the educational process as a basis for understanding tolerance.

Pedagogy, accumulating knowledge of related fields of science, interprets tolerance as: moral value (together with philosophy), personal education, personality quality (together with psychology), human virtue, active life position (together with sociology). It is important to understand tolerance as:

- a value or art of living in a world of different people and ideas, the ability to have rights and freedoms, without violating the rights and freedoms of others;

- an active life position based on the recognition of another;

- an attitude to people - acceptance of otherness, recognition of multidimensionality and identity of any culture, acceptance of norms and rules, refusal to reduce diversity to uniformity or dominance of any one point of view and position, understanding and acceptance of traditions, values and culture of other nationalities and religions;

- a quality of the child's personality that determines its characteristic behavior, activities and thinking (Rozlutska, Sokol, Ivanychko 2020, p. 96).

The above gives us grounds to identify the qualities of tolerance and to establish directions for their implementation in the communicative culture of the modern education manager (see Table 1). Tolerance is evidenced by the following manifestations in communication or the art of speech of the manager - normativeness, accuracy, logic, emotional expressiveness, relevance, content, variability, and others. The qualities that characterize the ethics of behavior include benevolence, a positive attitude of mercy, kindness, gentleness, compassion, and others. Tolerance in professionalism has been determined by the presence of a humanistic worldview, professional dignity and honor, self-criticism, restraint, moderation, impartiality, dynamism, emotional stability and others. The main strategies of the manager's behavior are: partnership, distributed leadership, equality of the parties, mutual respect, guardianship, the right to choose, voluntary obligations, fulfillment of agreements, etc..

Table 1. Directions of tolerance qualities realization in communicative culture of the modern education manager

\begin{tabular}{|c|c|c|}
\hline № & Tolerance qualities & Directions of realization \\
\hline & normativeness & \\
& precision & \\
& logic & \\
& relevance & \\
1. & content & \\
& variability & the art of speech \\
\hline & positive emotional coloring & \\
& goodwill & \\
\hline 2. & positive attitude & \\
& mercy & ethics of behavior \\
& kindness & \\
& empathy & \\
& mutual respect & \\
\hline 5. & professional dignity and honor & \\
& self-criticism & professionalism \\
\hline
\end{tabular}




\begin{tabular}{|c|c|c|}
\hline & $\begin{array}{c}\text { distributed leadership } \\
\text { equality of arms } \\
\text { dialogization } \\
\text { informatization } \\
\text { digital transactions }\end{array}$ & \\
\hline $\begin{array}{c}\text { impartiality } \\
\text { the right to choose } \\
\text { voluntary commitment } \\
\text { fulfillment of agreements }\end{array}$ & \\
4. & \\
\hline
\end{tabular}

The defining characteristic of a tolerant communicative culture is the awareness of the differences of the communication partner, as well as the differences of his motivations, intentions, background knowledge, code (language, gestures, symbols, etc.). It is also important to be aware of each other - communication partners as "foreign" on the basis of different historical developments, cultures, main codes or meanings, oppositions and categories through the prism of identity. Tolerance as a desire to establish a positive interaction between people who differ in some respects or do not adhere to generally accepted ideas and norms (Darmoriz 2000, p. 225).

Thus, from a practical point of view, tolerance in the communicative culture of a modern education manager can be defined as:

- a strategy of establishing and developing relationships between people, which involves the exchange of information, certain tactics and strategies of interaction, direction and mutual understanding between communication subjects;

- a behavior regulator, guarantor of respectful attitude of the individual to others, their understanding, patience and mutual respect;

- one of the mechanisms of harmonization of personal and professional interests.

\section{Conclusions and prospects for further researches}

The study has been presented as a basic definition of the communicative culture of the education manager as an integrative personality trait, which is positioned with the interaction of participants in the educational process, the creative potential of the manager, his ability to maintain a friendly attitude to others. It has been proved that in the conditions of modern integration challenges tolerance testifies to the development level of communicative culture of education manager.

Based on the results, a structural and semantic model of tolerance in the communicative culture of the education manager has been developed. It has been found that tolerance as a part of the value basis of communicative culture is manifested in personal and social values, norms of behavior. This concept has been formed under the influence of external and internal factors, in particular through self-improvement and continuing education. The most important for educational management types of communicative culture, which enable manifestations of tolerance, in particular: the case of communication, system-forming and integrating social factor, sectoral aspect) have been singled out. The education manager structure includes conceptual-target, content, functional, evaluation-performance components of modern teaching process.

\section{References}

Barchiy M., Voronova O. (2020) Value orientations in the structure of personality orientation. Scientific Bulletin of Mukachevo State University. Pedagogy and Psychology Series ". Mukachevo, \#. 1 (11). P. 252-255.

Bezklubenko S. (2011) Morphology Aspects of Ukraine's Culture: genesis, typology: collection. Kyiv:NAM Ukraine. 288 p.

Bondarchuk O. I. (2008) Socio-psychological bases of personal development of heads of general educational institutions in professional activity: monograph. Kyiv: Nauk. Svit. 318 p.

Darmoriz O. V. (2000) Tolerance in the field of interethnic cultural communication. Lviv: Lviv Polytechnic National University Institutional Repository. URL: http://ena.lp.edu.ua

Kolomensky N. L. (2000) Psychology of management in education (socio-psychological aspect): monograph. Kyiv: IAPM. 286 p. 
Lurina T., Molodychenko N., Kovalenko M. (2015) Formation of communicative culture of future teachers. Pedagogy. Bulletin of Taras Shevchenko National University of Kyiv, Kyiv. P. 5053.

Mariana Sokol, Olga Tsaryk, Galyna Rozlutska, Nadiya Hupka-Makohin and Iryna Horenko. The System of Pedagogical Concepts in Globalization Conditions. International Journal of Applied Exercise Physiology. Vol. 9 (4). P. 43-52. URL: http://ijaep.com/Journal/vol.9.4.pdf

Naumchuk I.A. (2019) Development of professional culture of the head of out-of-school educational institution in the system of postgraduate pedagogical education. Autoreferat. Kyiv: NAPN. $38 \mathrm{p}$.

Panchenko V. (2014) Communicative culture of the future specialist: theoretical analysis. Scientific Bulletin of the Lesia Ukrainka East European National University. . P. 49-52

Rozlutskaya G.M., Kostak N.I., Sharkadi M.I. (2019) Pedagogy of partnership as a core of a new formation teacher professionalism. Education and formation of competitiveness of specialists in the conditions of European integration": collection of abstracts of the III International scientific-practical conference. Mukachevo. P.408-410.

Rozlutskaya G.M., Sokol M.O., Ivanychko I.I. (2020) Transformation of the principle of cultural conformity in the organization of a tolerant educational space. Problems and Innovations in Science. Abstracts of the 1st International scientific and practical conference. Great Britain London: Nika Publishing, V.2 Pp. 95-100. URL: http://elconf.com.ua/

Shatun V.T. (2006) The base of management. Mykolaiv: Published by Moscow State University. Petra Mogili, $376 \mathrm{p}$.

Skibitska L. I. (2010) Organization of the manager. Teaching. manual. Kyiv: Center for Educational Literature. $360 \mathrm{p}$.

Svyatokha N. A. (2013) The influence of the management culture of the head of the higher educational institution on the effectiveness of management. Theoretical and applied problems of psychology. Kyiv, P. 227-233.

Vegesh I. M. (2019) The evolution of tolerance concept in world scientific thought. Tolerance on the borders of Europe: a dimension for Ukraine. Proceedings of the international scientificpractical conference. Uzhhorod: Naumchenko. P. 21-24.

Virtual Resource]/ Francis Wardle//The Professional Resource for Teachers and Parents. URL: http://www.earlychildhoodnews.com/earlychildhood/article_view.aspx? ArticleID=548 